Research article

\title{
Forested versus herbaceous wetlands: Can management mitigate ecohydrologic regime shifts from invasive emerald ash borer?
} \author{
Brian J. Palik ${ }^{\mathrm{d}}$ \\ a School for Forest Resources and Environmental Conservation, Virginia Polytechnic University, Blacksburg VA, USA \\ ${ }^{\mathbf{b}}$ Minnesota Forest Resources Council, St. Paul MN, USA \\ ${ }^{\mathrm{c}}$ Rubenstein School of Environment and Natural Resources, University of Vermont, Burlington VT, USA \\ ${ }^{\mathrm{d}}$ USDA Forest Service, Northern Research Station, Grand Rapids MN, USA
}

Jacob S. Diamond ${ }^{\mathrm{a}, *}$, Daniel L. McLaughlin ${ }^{\mathrm{a}}$, Robert A. Slesak ${ }^{\mathrm{b}}$, Anthony W. D'Amato ${ }^{\mathrm{c}}$,

\section{A R T I C L E I N F O}

\section{Keywords:}

EAB

Fraxinus nigra

Evapotranspiration

White method

Wetting up

\begin{abstract}
A B S T R A C T
Wetlands self-organize through reciprocal controls between vegetation and hydrology, but external disturbance may disrupt these feedbacks with consequent changes to ecosystem state. Imminent and widespread emerald ash borer (EAB) infestation throughout North American forested wetlands has raised concern over possible ecosystem state shifts (i.e., wetter, more herbaceous systems) and loss of forest function, calling for informed landscape-scale management strategies. In response, we employed a large-scale manipulative study to assess the ecohydrologic response of black ash wetlands to three alternative EAB management strategies: 1) a do-nothing approach (i.e., simulated EAB infestation via tree girdling), 2) a preemptive, complete harvesting approach (i.e., clearcut), and 3) an overstory replacement approach via group selection. We analyzed six years of daily water table and evapotranspiration (ET) dynamics in six blocks comprising black ash wetlands (controls) and management strategy treatments to quantify potential for hydrologic change and subsequent recovery. In both the do-nothing approach and complete harvesting approach, we found persistent changes in hydrologic regime defined by shallower water tables and lower ET rates coupled with increased herbaceous vegetation growth, indicating ecosystem state shifts driven by vegetation-water table interactions. The do-nothing approach showed the least hydrologic recovery after five years, which we attribute to reduction in overstory transpiration as well as greater shade (via standing dead trees) that reduces open water evaporation and herbaceous layer transpiration compared to complete harvesting. We found no evidence of ecohydrologic disturbance in the overstory replacement approach, highlighting its potential as a management strategy to preserve forested wetland habitat if periodically executed over time before EAB infestation. Although the scale of potential disturbance is daunting, our findings provide a baseline assessment for forest managers to develop preemptive mitigation strategies to address the threat of EAB to ecological functions in black ash wetlands.
\end{abstract}

\section{Introduction}

Wetlands self-organize through reciprocal controls between vegetation and hydrology. In contrast to uplands, hydrologic controls on wetland vegetation are generally the result of too much rather than too little water (Jackson and Colmer, 2005). This abundance of water results in inadequate oxygen supply (Armstrong and Drew, 2002) and accumulation of ethylene and anaerobic metabolism byproducts (Ponnamperuma, 1984), limiting primary production and preferentially selecting for flora with special adaptations (Kozlowski, 2002; Kreuzwieser and Rennenberg, 2014). At the same time, wetland vegetation controls local hydrology directly through evapotranspiration
(ET), which lowers water tables and reduces soil moisture (Marani et al., 2006). These ecohydrologic interactions often enable and promote ecosystem stability (Rodríguez-Iturbe et al., 2007). However, shifts to different ecosystem states can occur with disturbance to hydrologic setting (e.g., flooding, climate; Wang et al., 2016) or vegetation dynamics (e.g., widespread mortality, Heffernan, 2008).

In black ash (Fraxinus nigra) wetlands of North America, looming threats of emerald ash borer (EAB; Agrilus planipennis) infestation have drawn attention to possible large-scale tree mortality and a resultant whole-scale shift in ecosystem type and function. EAB causes nearly $100 \%$ mortality in all ash species within 3-6 years after infestation (Knight et al., 2013), and there is no known host physiological

\footnotetext{
* Corresponding author.

E-mail address: jacdia@vt.edu (J.S. Diamond).
} 
resistance or stand characteristic that inhibits infestation (Smith et al., 2015). Ash regeneration is also susceptible to $E A B$ colonization once it reaches $2.5 \mathrm{~cm}$ in diameter (Klooster et al., 2014), limiting the potential for reestablishment in the presence of EAB. The extent of EAB infestation is widespread, occurring in 27 U.S. states and two Canadian Provinces as of 2017 (USDA, 2017). Impending infestation throughout the upper Midwestern United States is particularly concerning, as black ash wetlands cover approximately $8000 \mathrm{~km}^{2}$ and provide myriad functions ranging from shelter and food for wildlife (Anderson and Nelson, 2003) to timber and non-timber forest products (Wright and Rauscher, 1990).

Widespread black ash mortality may equate to loss of a wetland foundational species (sensu Ellison et al., 2005), with important consequences for ecohydrologic interactions and successional trajectories (Youngquist et al., 2017). Throughout the upper Midwestern United States, black ash wetlands are highly monospecific, with black ash comprising $75-100 \%$ of canopy cover. In these monospecific stands, complete canopy loss following EAB may cause the water table to rise (via reduced transpiration) and favor establishment and growth of other more water tolerant vegetation, particularly marsh species (Erdmann et al., 1987). Recent studies support this general prediction, where canopy disturbance in black ash wetlands resulted in wetter conditions (Slesak et al., 2014) and associated large shifts in species composition towards a herbaceous community (Davis et al., 2016; Looney et al., 2017). Given the extensive coverage and regional importance of black ash wetlands, it is now important to explore possible consequences (and mitigation) of EAB disturbance on ecosystem interactions, state, and function.

Reduced ET is the putative mechanism for expected water table rise and ecosystem state shifts following EAB-induced mortality, but actual changes in ET and how such changes vary over time (seasons to years) and with vegetation structure remain largely unexplored. Although previous studies made a clear link between black ash mortality and altered hydrology (Slesak et al., 2014), the lack of direct ET measurements leaves open questions regarding how black ash regulates water tables compared to other vegetative communities. Post-disturbance community composition, growth, and associated ET rates are likely driven by both hydrologic regime and remnant vegetation structure and recovery, highlighting potential implications of management options that range from a do-nothing approach (i.e., leave standing dead trees) to different degrees of preemptive tree harvest (i.e., partial versus clearcutting). Confronting this knowledge gap, we posit a conceptual model of ET drivers that vary with vegetation structure and thus different management strategies (Fig. 1). This model includes availability of energy (e.g., shade from standing dead versus open canopy in a complete clear cut) and water (e.g., via differences in rooting depths), with associated feedbacks to water table regime and its control on post- disturbance vegetative communities. Evaluating this model will address more directly the interactions among energy, vegetation, and hydrology in black ash ecosystems, with implications for both recovery times and management options.

Here, we build upon earlier work (Slesak et al., 2014) by integrating multi-year measures of both daily water table and ET dynamics across black ash wetlands that represent different management options and thus vegetation structure: intact black ash stands (controls), simulated EAB-induced mortality (girdled; do-nothing approach), and two management mitigation options (clearcut and group selection harvest) (Fig. 1b-d). Our overarching objective was to assess outcomes of both $\mathrm{EAB}$ infestation and management options on post-disturbance hydrologic regime. We hypothesized that: H1) water table regimes and their possible post-disturbance recovery will vary depending on management strategy and thus vegetation structure, and H2) that differences in water table regimes among management options can be explained by coincident differences in ET, where black ash trees exhibit unique ET regimes relative to post-disturbance replacement vegetation. Our research advances fundamental understanding of ecohydrologic interactions in black ash wetlands and has direct implications for management aimed at mitigating consequences of EAB infestation.

\section{Methods}

\subsection{Landscape setting}

Our study sites were located within the Chippewa National Forest in northern Minnesota, USA, a $2700 \mathrm{~km}^{2}$ area with $1600 \mathrm{~km}^{2}$ of wetlands and over 1300 lakes (Fig. 2). The area encompasses a complex glacial landscape that is flat to gently rolling, with black ash wetlands found in the lowest landscape positions that commonly grade into aspen ( $\mathrm{Po}$ pulus) or pine (Pinus)-dominated upland forests. Most of the black ash wetlands are underlain by lacustrine clay at a depth of $10-150 \mathrm{~cm}$ that acts as a confining layer and creates wetland hydrologic conditions (seasonal soil saturation and inundation). Specific soil types vary and include Typic Glossaqualfs with no O horizon, Histic Humaquepts with a $30 \mathrm{~cm}$ deep $\mathrm{O}$ horizon, and Terric Haplosaprists with a $60 \mathrm{~cm}$ deep $\mathrm{O}$ horizon and no B horizon (Soil Survey Staff, 2014). However, collected soil samples in our study sites did not significantly differ in overall soil chemistries (total carbon and nitrogen) or bulk densities (Table S1).

Forest structure and composition in black ash stands in the region are characterized by black ash canopy dominance (75-100\%) co-occurring with American elm (Ulmus americana), balsam fir (Abies balsamea), basswood (Tilia Americana), red maple (Acer rubrum), yellow birch (Betula alleghaniensis), quaking aspen (Populus tremuloides), or white cedar (Thuja occidentalis). Stands are typically strongly uneven-

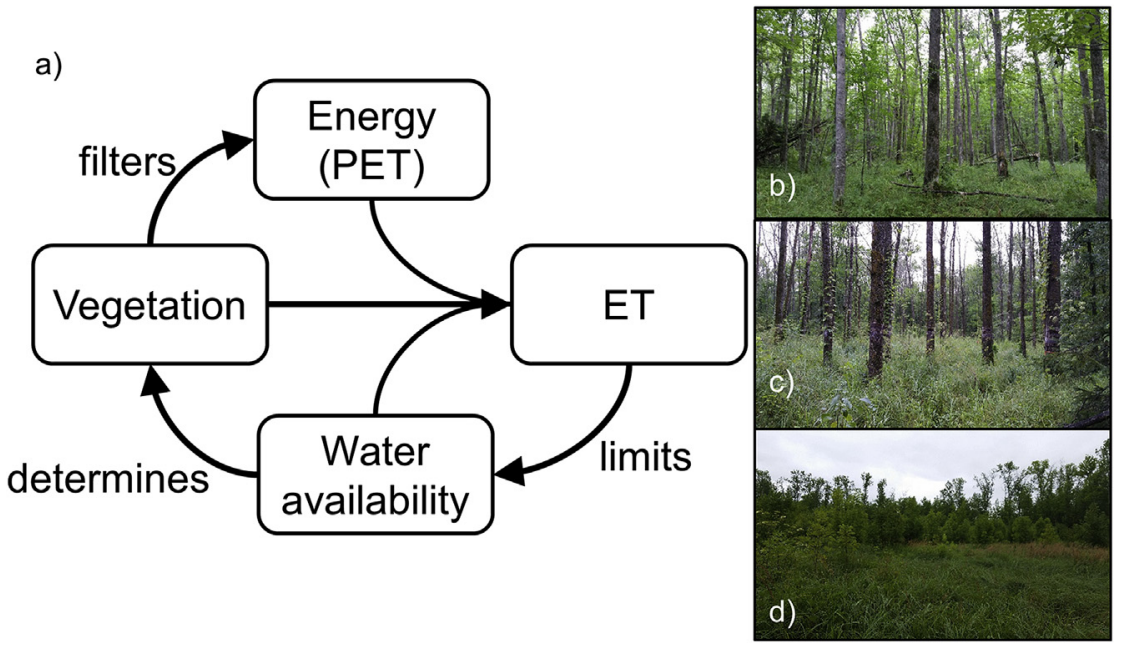

Fig. 1. a) Conceptual model of feedbacks driving ecohydrology of black ash wetlands. Energy from solar radiation and wind (potential evapotranspiration, PET) is filtered through a cascading vegetation structure to drive evapotranspiration (ET) under the combined influence of vegetation and water availability. ET limits water availability through depletion and controls seasonal water table patterns, which in turn determine vegetation species composition and structure. Photos b-d are from treatment plots in August 2015 that are in similar in environmental conditions (e.g., climate, soils, and elevation) but differ in vegetation structure and its influence on energy partitioning: b) example of black ash wetland with energy filtered by the canopy strata; c) example of girdled black ash wetland to simulate EAB mortality with less energy filtered by the canopy strata; d) example of clearcut black ash wetland with increased growth of marsh vegetation due to large reduction in energy filtered from the canopy strata. 


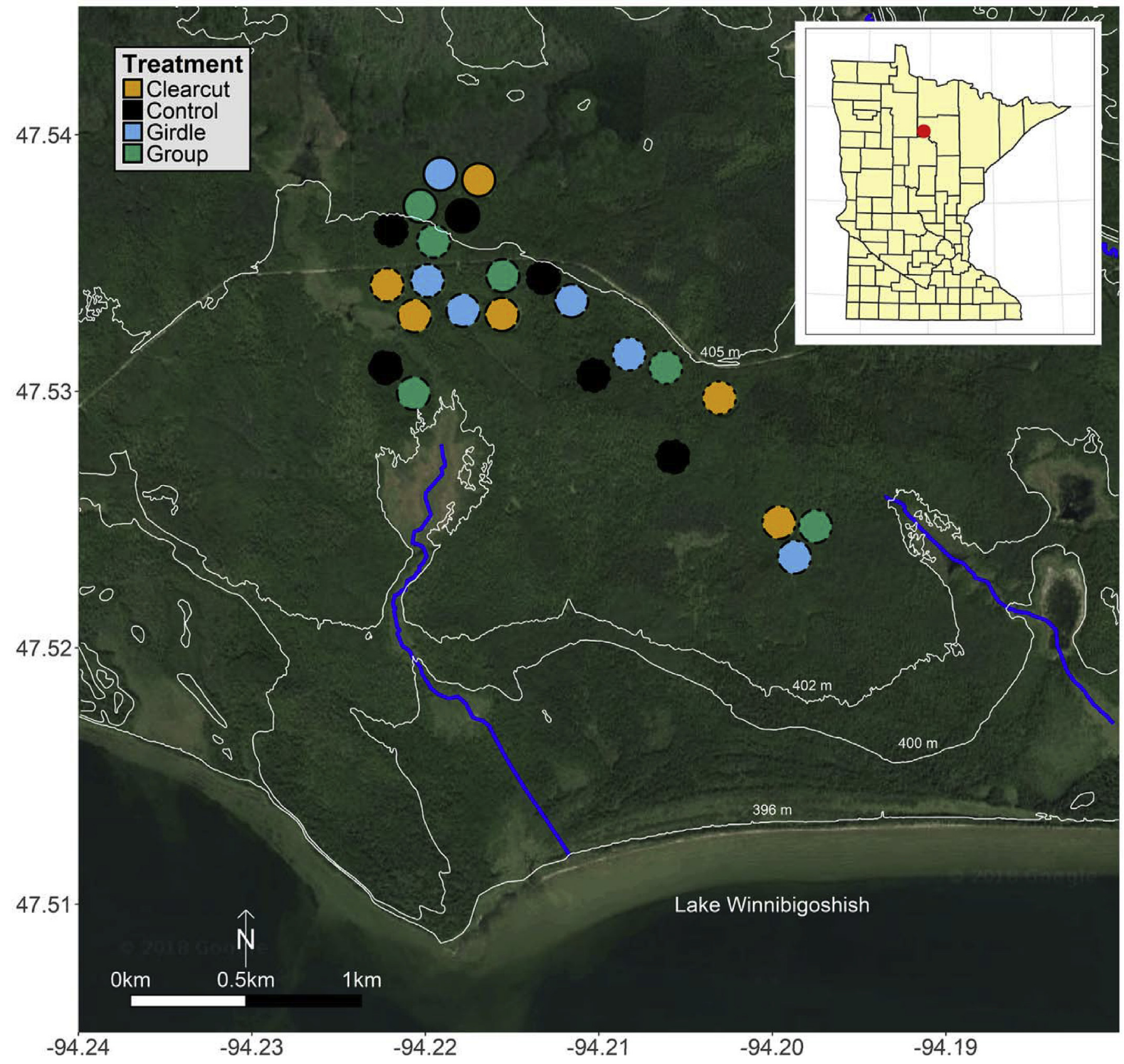

Fig. 2. Experimental design of EAB study in Chippewa National Forest. Blocks 1-6 are shown. Line types surrounding experimental plots designate blocks. White lines are contour lines and dark blue lines are intermittent streams. Wells are located in the center of each plot, with two co-located rain gages in blocks 1 and 3 control plots. (For interpretation of the references to color in this figure legend, the reader is referred to the Web version of this article.)

aged and largely influenced by gap-scale disturbance processes with canopy tree ages ranging from 130 to 232 years (Looney et al., 2016). In our study sites, basal areas prior to treatment (see below) ranged from 23.0 to $39.2 \mathrm{~m}^{2} \mathrm{ha}^{-1}$, and densities ranged from 563 to 917 stems ha $^{-1}$.

Mean annual precipitation at the study area is $70 \mathrm{~cm}, 60 \%$ of which is via rainfall. Mean growing season (May-September) temperature is $14.3^{\circ} \mathrm{C}$, and annual potential ET (PET) is $60-65 \mathrm{~cm}$ (Sebestyen et al., 2011). Hydrologic monitoring and water geochemistry investigations indicate that black ash wetlands are mostly disconnected from the regional groundwater system (via the shallow confining layer), and are largely precipitation driven with snowmelt in the spring and periodic inputs via rainfall throughout the growing season (Slesak et al., 2014). The regional confined groundwater system ranges in depth from 1.5 to
$17 \mathrm{~m}$, with a general horizontal flow direction south towards Lake Winnibigoshish; vertical groundwater flow in the study area is minimal (Lindgren, 1996).

\subsection{Experimental design}

We established a large-scale, manipulative study using a randomized complete block design with six blocks, each with four 1.6 ha circular treatment plots that were similar in elevation and soils (Fig. 2). Blocks were delineated based on three criteria: 1) plot proximity, 2) general assessments of pretreatment hydrologic regime (e.g., wet vs. relatively drier), and 3) native plant communities. Four treatments were applied within each block, providing 6 replications of each treatment: 1) control, 2) girdling of all black ash trees down to $10 \mathrm{~cm}$ 
diameter at $1.3 \mathrm{~m}$ height ("girdle"), 3) group selection harvest (20\% of stand in 0.04 ha gaps; "group selection"), and 4) clear cut harvest (complete removal of all trees; "clearcut"). The girdling treatment mimicked EAB induced mortality, including progressive ash mortality over several years and retention of standing dead trees on site. The two forest harvesting treatments represented possible management strategies to modify stand composition and facilitate natural regeneration or planting of alternative tree species to maintain forest ecosystem functioning following EAB infestation. All treatments were applied in winter of 2011-2012 during frozen ground conditions, and trees in girdle treatments were re-girdled in the winter of 2012-2013 to ensure $100 \%$ mortality. Drawknives were used for manual application of the girdle treatments, and cut-to-length mechanized harvest systems were used for the clearcut and group selection treatments. Previous research documented shifts from woody to herbaceous species after girdle and clearcut treatments were implemented (Looney et al., 2016, Looney et al., 2017, Fig. 1c and d). Clearcut treatments became dominated by Canada reedgrass (Calamagrostis canadensis), whereas girdle treatments promoted growth of rhizomatous ferns (Matteuccia struthiopteris) and sedges (Carex radiata).

\subsection{Data collection}

Over a six-year period (2011-2016), we monitored water table levels throughout the snow-free season (typically May through October) in all experimental plots using groundwater monitoring wells. Wells were constructed of 5-cm diameter, screened PVC pipe and located in the approximate center of each plot to a depth of $1.5 \mathrm{~m}$ or until a confining layer was reached. We measured water levels with high-resolution total pressure transducers (Levelogger Gold Model 3001, Solinst Canada Ltd, Ontario, Canada; and HOBO U20L-04, Onset Computer Corp., Bourne, MA) at 15-min intervals, and corrected for atmospheric pressure with a barometric pressure logger (Barologger, Solinst Canada Ltd, Ontario, Canada). We also recorded rainfall with four HOBO tipping-bucket rain gauges (model RG3-M, Onset Computer Corp., Bourne, MA) located on-site, and obtained local potential evapotranspiration (PET) values and total annual precipitation values (i.e., including snowfall) from the nearby RAWS Cutfoot station (http:// www.raws.dri.edu/cgi-bin/rawMAIN.pl?sdMCUT). To assess effects of differences in canopy on energy budgets, air temperature was measured using Thermochron iButtons (model Ds1921G-F5, Maxim Integrated, San Jose CA) at $0.5 \mathrm{~m}$ height from 2013 to 2016 in controls, girdle, and clearcut treatments.

\subsection{Data analysis}

We used collected data to quantify and compare pre- and posttreatment water table regimes and ET rates (also derived from water table data) across treatment groups. We first passed water table data through a digital, second-order Butterworth low-pass filter to improve the signal-to-noise ratio. For each well, we also removed all days when water tables were below sensor depth. We conducted all data processing and subsequent analyses using R (R Core Team, 2016).

\subsubsection{Water table regimes}

To assess treatment-induced water table changes, we employed a paired-plot approach (sensu Pothier et al., 2003). Within each block, we calculated annual pretreatment (2011) and post-treatment (2012-2016) relationships between control water tables and water tables for each manipulative treatment (i.e., girdle, group, and clearcut) using simple linear regressions of average daily water tables. We then normalized all annual post-treatment relationships relative to pretreatment relationships to account for pretreatment differences among blocks. Doing so allowed treatments to be pooled across replicates (i.e., across blocks) and for a more general interpretation of treatment effect (vis-à-vis 1:1 pretreatment relationships). To do so, we divided post- treatment slopes by pretreatment slopes (e.g., if the pre-treatment slope was 1.2 and the post-treatment slope was 0.6 , then the normalized slope would be 0.5 ) and subtracted pre-treatment intercepts. To account for possible piecewise behavior in post-treatment normalized relationships (e.g., slope shifts at specific thresholds), we used the segmented package in R (Muggeo, 2003; 2008) to test the null hypothesis of a constant linear predictor. Where this null hypothesis was rejected $(\mathrm{p}<0.05)$, we conducted breakpoint analysis to estimate the fit for a model constrained to two slopes. Our model did not specify breakpoint values $a$ priori, but instead optimized each breakpoint location by iteratively fitting standard iteratively-reweighted least squares models. For each normalized post-treatment relationship, we extracted relationship parameters (y-intercept, x-axis breakpoint, and slopes), pooled by treatment (via parameter means across replicates), and tested for significant differences both across treatments and compared to pretreatment predictions (null hypothesis: slope $=1$, intercept $=0$, and no breakpoint).

Normalized post-treatment relationships revealed effects of manipulative treatments in several ways. Deviations from pretreatment predictions (i.e., 1:1 relationship) indicated increased or decreased posttreatment water tables and under what conditions (e.g., shallow versus deep water tables). A normalized post-treatment slope less than unity indicated a reduced water table drawdown rate relative to pre-treatment predictions, whereas a slope greater than unity indicated a more rapid drawdown rate. The presence of breakpoint indicated a shift in drawdown rates at specific water table conditions. A normalized posttreatment intercept greater than zero indicated higher post-treatment maximum water tables relative to pre-treatment predictions, and the opposite for an intercept less than zero. As such, annual normalized relationships allowed assessment of both treatment effects and degree of hydrologic recovery over time.

\subsubsection{Evapotranspiration rates}

We calculated daily ET using a modified White method (1932) first described by Loheide et al. (2005) and used recently by Watras et al. (2017). The method is applied for non-rain days and assumes ET is negligible at night, allowing daily ET to be estimated from 24-hr change in water table and variable net groundwater inflow:

$E T=S_{y} \times[r-S]$

where: $\mathrm{ET}=$ daily evapotranspiration [L] $\mathrm{S}_{\mathrm{y}}=$ specific yield as a function of water table [-] $\mathrm{r}=$ net groundwater inflow as a function of detrended water table [L] S $=24$-hr change in storage (change in daily water table) [L].

We estimated variable groundwater inflow ( $r$ ) as a function of detrended water table data following methods described in Loheide et al. (2005). We used a three-day sliding window to detrend the water table data because our data did not have one consistent trend over a season due to punctuated rain events and variable drawdown rates over the season. Eq. (1) also requires specific yield $\left(\mathrm{S}_{\mathrm{y}}\right)$ values, defined as the depth of water released or gained from storage per unit change in water table. Sy varies with both below- (Duke, 1972) and above-ground water levels (McLaughlin and Cohen, 2014), requiring constructed relationships between $\mathrm{S}_{\mathrm{y}}$ and water table levels. Similar to Watras et al. (2017) and following methods described in McLaughlin and Cohen (2014), we empirically estimated $S_{y}$ values as ratios of rain (corrected for interception) to induced water table rise across different precipitation events (and water table levels) to construct $\mathrm{S}_{\mathrm{y}}$ relationships for each plot. Across plots, our water table-dependent $S_{y}$ functions followed an exponential curve from water tables levels at approximately $-10 \mathrm{~cm}$ (10 $\mathrm{cm}$ below ground surface) to $5 \mathrm{~cm}$ above ground surface. Generally, below $-10 \mathrm{~cm}, \mathrm{~S}_{\mathrm{y}}$ was approximately constant at 0.05 , and above $5 \mathrm{~cm}$, $\mathrm{S}_{\mathrm{y}}$ was approximately constant at 0.8 .

We calculated daily ET for every day without rainfall at each of our plots. We conducted quality control by removing data with poor signalto-noise ratios in diurnal water table variation (typically due to recent 
rainfall) that limited ET estimation. To evaluate differences in ET among treatments, we differenced daily ET in manipulative treatments (girdle, group, and clearcut) with daily control ET within each block ( $\mathrm{ET}_{\text {treatment,i }}-\mathrm{ET}_{\text {control, } \mathrm{i}}$ ), but only on days where both the treatment plot and the control plot within a block had ET estimates. Then we averaged daily differences by treatment (across blocks) and month for each year of the study. We also conducted unequal variances t-tests for each month to test the null hypothesis that controls versus manipulative treatments had equal mean monthly ET rates. Overall, we used 14,354 days for the ET analysis, 8016 of which were days when we could compare control ET to treatment ET within a block.

To test our conceptual model, we employed a linear mixed-effects model to predict daily ET averaged by month using our hypothesized ET drivers as predictors (Fig. 1a): 1) monthly average of daily PET for climatic demand; 2) average monthly water table position for water availability, 3) treatment for differences in both vegetation transpiration (e.g., via differences in water use efficiency and rooting depth) and structure (shading and canopy turbulence); and 4) vegetation phenology (i.e., leaf off or leaf on, assuming a leaf on period of June 1 to September 30). We used the control plots as our reference group. We also considered the interaction of average monthly water table position with treatment to account for the expected treatment differences in water table-dependent ET response. In addition to focusing on specific drivers, this combination of variables provided the lowest Bayesian Information Criterion scores and the highest likelihood scores relative to both simpler and more complex alternative models (e.g., no phenology term, multiple interaction terms, and no interaction terms). We modeled treatments nested within blocks as a random effect. We also used an autoregressive (AR1) correlation matrix structure to account for the high degree of autocorrelation among consecutive months; we confirmed this to be a reasonable correlation structure based on improvement of the autocovariance plot after implementation. We also found improvement in residual behavior, and note that residuals were normally distributed about zero. Finally, to allow for model estimate comparison between the two quantitative variables (PET and average monthly water table), we also considered a model where PET and average monthly water table were centered and scaled to the same range.
Table 1

Mean ( \pm standard error) evapotranspiration and rainfall across control plots for study period (2011-2016).

\begin{tabular}{llll}
\hline Month & $\begin{array}{l}\text { Average Daily } \\
\text { Evapotranspiration }(\mathrm{cm})\end{array}$ & $\begin{array}{l}\text { Average Monthly } \\
\text { Evapotranspiration }(\mathrm{cm})\end{array}$ & $\begin{array}{l}\text { Average Monthly } \\
\text { Rainfall }(\mathrm{cm})\end{array}$ \\
\hline 5 & $0.21 \pm 0.0056$ & $6.4 \pm 0.17$ & $7.9 \pm 0.37$ \\
6 & $0.31 \pm 0.0078$ & $9.2 \pm 0.23$ & $11 \pm 1.3$ \\
7 & $0.42 \pm 0.021$ & $13 \pm 0.63$ & $7.5 \pm 1.3$ \\
8 & $0.36 \pm 0.041$ & $11 \pm 1.2$ & $5.2 \pm 0.18$ \\
9 & $0.17 \pm 0.0053$ & $5.0 \pm 0.19$ & $5.9 \pm 2.0$ \\
10 & $0.12 \pm 0.0053$ & $3.6 \pm 0.16$ & $2.7 \pm 1.4$ \\
11 & $0.040 \pm 0.0043$ & $1.2 \pm 0.13$ & $0.21 \pm 0.15$ \\
Total & - & 49 & 40 \\
\hline
\end{tabular}

\section{Results}

There were common hydrologic patterns across all treatments, best described as early season inundation followed by consistent summer drawdown with occasional punctuated rainfall events raising water tables (Fig. 3). We also observed consistent diel signals in water table data (Fig. 3 inset) indicative of ET signals and their variability across treatments. There was little interannual variation among control treatment ET rates, with much greater variation in the timing and amount of total rainfall across years (Table 1); monthly rainfall and control ET were not correlated $(\mathrm{p}=0.33)$ across years. Overall annual precipitation (obtained from the RAWS Cutfoot site) was greatest in $2016(90.7 \mathrm{~cm})$ and least in $2013(59.2 \mathrm{~cm})$. Rainfall was most frequent in 2013, 2014 and 2016, which experienced an average 0.4 events day $^{-1}$, but 2016 had the largest events, with average event size $40 \%$ greater than other years. Despite this wide interannual variability in precipitation inputs, we observed coherent effects of manipulative treatments on both water table regimes and ET rates.

\subsection{Treatment effects on water table regimes}

Across all plots, pre-treatment relationships between control and manipulative treatment daily water tables were highly linear, had

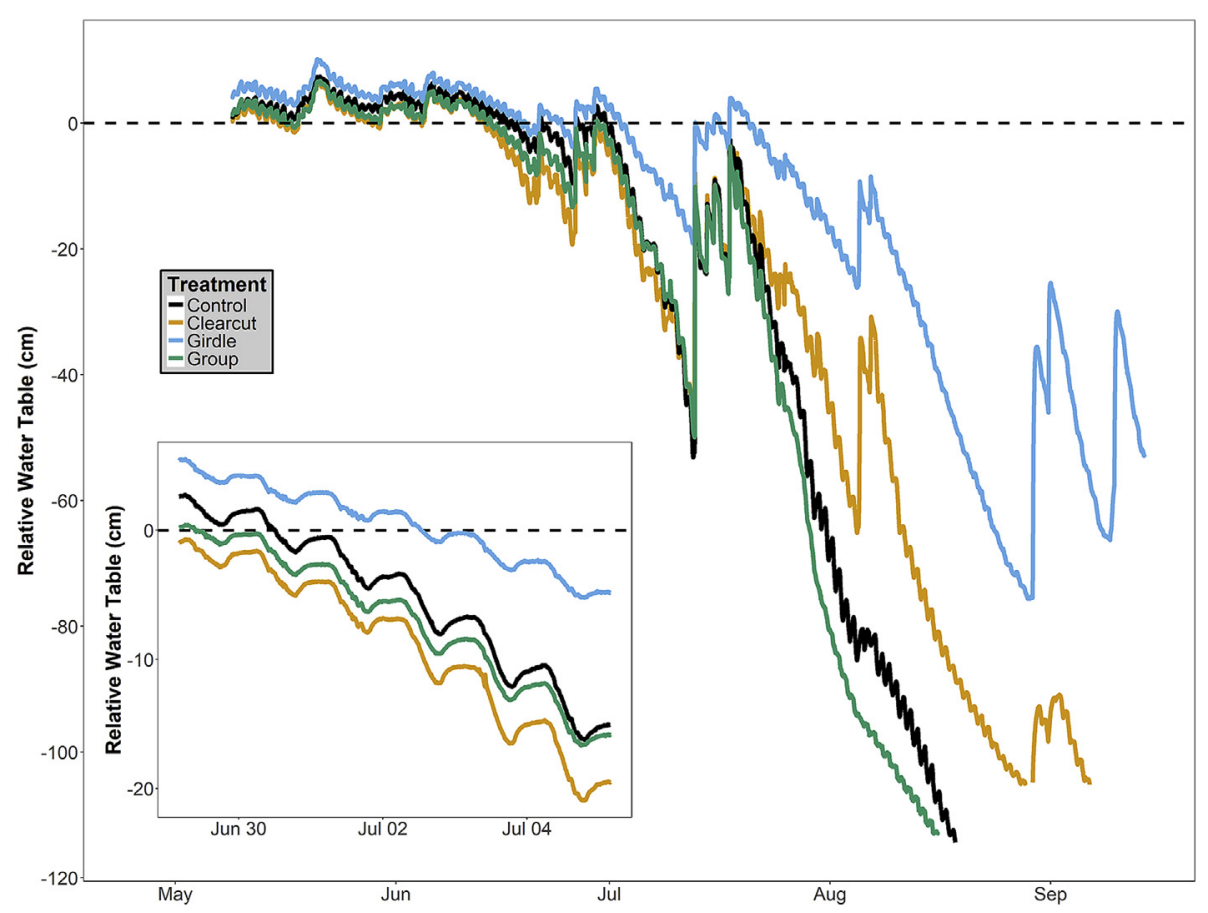

Fig. 3. Example of water table patterns for each of the treatments (Block 1, 2013), with inset of diurnal patterns. Dashed line denotes ground surface. 
a)

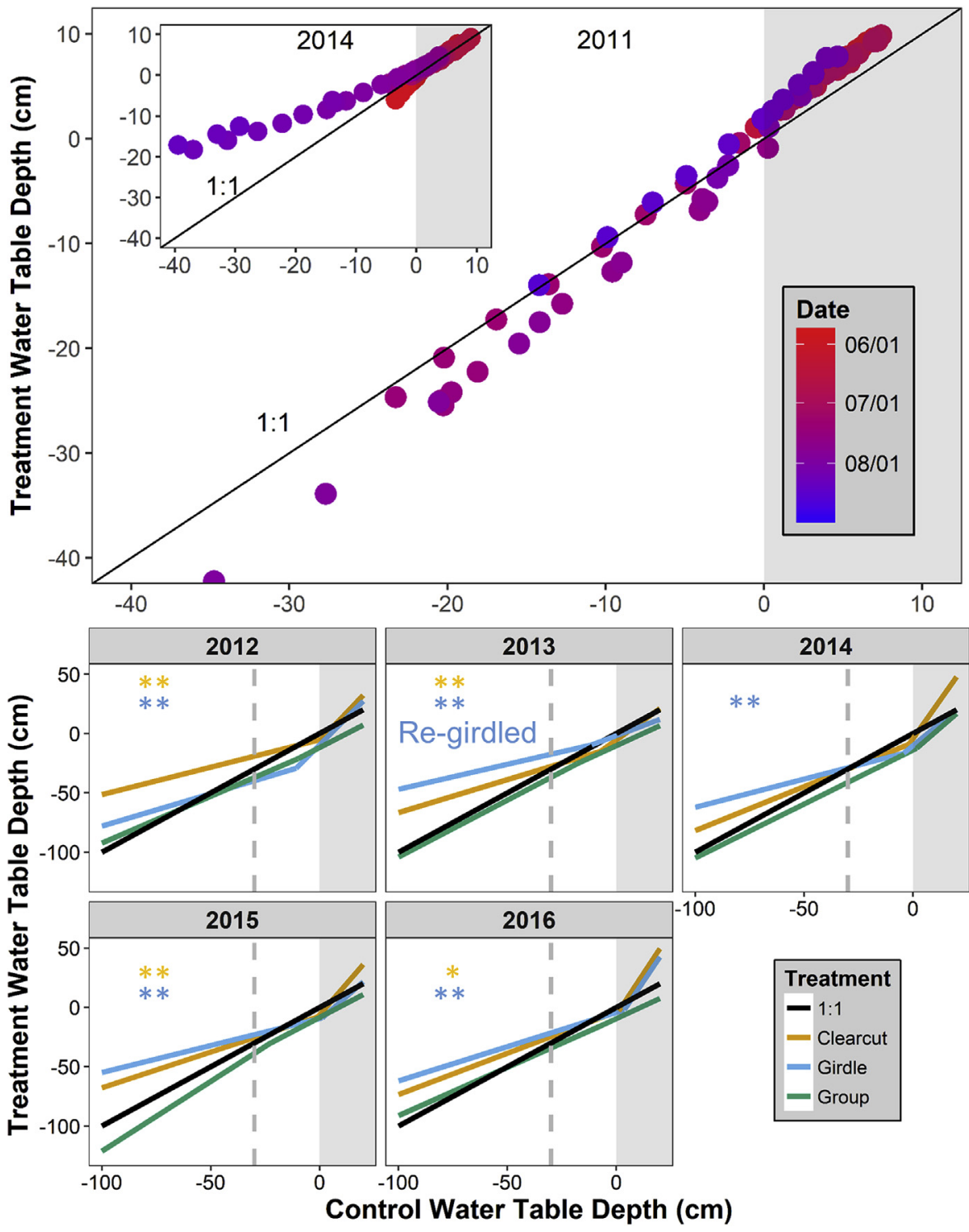

Fig. 4. a) Example water table comparison in block 1 between girdle and control in pretreatment year (2011) and post-treatment year (2014; inset). Points are colored by the date they were recorded. Note difference between nearidentical 1:1 behavior in pre-treatment year (2011) compared to breakpoint behavior in post-treatment year (2014). b) Average water table response across 6 blocks. Black 1:1 line represents rescaled 2011 pre-treatment relationship. Asterisks represent slopes significantly different from the $1: 1$ line (*, $\mathrm{p}<0.05 ; * *, \mathrm{p}<0.01$ ). Slopes above breakpoints were often significantly greater than 1 within sites, but not when averaged among sites. Breakpoints predominately occurred at ground surface in the control (shading). Clearcut treatments appear to have a slightly faster recovery to pre-disturbance hydrology on average than girdle treatments, but both treatments maintain elevated water tables even after 5 years. The greatest differences in water table are observed below the grey line at $30 \mathrm{~cm}$ below ground surface. Group treatments do not significantly deviate from pre-treatment behavior. slopes near 1 (slope $=1.1 \pm 0.6$ ), and exhibited small variation about the best fit lines $\left(R^{2}=0.87 \pm 0.16\right)$, indicating a high degree of similarity in hydrologic behavior among plots within blocks (e.g., 2011 in Fig. 4a). Plots exhibited common water table drawdown behavior across blocks and years with generally high early season water tables followed by drawdown leading to deeper late season water tables (Fig. 4a, colors), corresponding with general trends shown in time series (Fig. 3). Following treatment, there were significant differences between mean (across blocks) normalized post-treatment relationships and pre-treatment relationships (i.e., deviation from the 1:1 line) for both clearcut and girdle treatments, with water tables being consistently higher in these treatments relative to predicted values (Fig. 4a and b). Deviation in girdle treatments was more evident following regirdling in 2013, suggesting limited mortality in the first year. When water tables were deepest for control plots $(\mathrm{ca} .-100 \mathrm{~cm})$, clearcut and girdle treatment water tables were up to $50 \mathrm{~cm}$ higher on average than predicted (some replicates deviated by as much as $80 \mathrm{~cm}$ ), but differences were markedly less at shallower water tables (Fig. 4a and b). Clearcut and girdle treatments exhibited similar initial response to disturbance (compare clearcut in 2012 and girdle in 2013), but girdle treatments maintained shallower relative water tables and lower drawdown rates than clearcut treatments throughout the five-year study period (e.g., in 2014 when clearcut normalized slopes were not significantly different than unity; Fig. 4b). Group treatments exhibited no significant departures from pre-treatment relationships in any year of the study period.

We observed ubiquitous piecewise post-treatment behavior across all blocks in both clearcut and girdle treatments (Fig. 4b). In nearly all years, both clearcut and girdle treatments exhibited a mean normalized slope greater than unity above a mean breakpoint consistently centered on the ground surface (shaded region in Fig. 4b). Below the breakpoint, however, normalized slopes were consistently less than unity. We also observed similarity between clearcut and girdle treatments in the relative location of departure from control water tables; the greatest differences between these treatments and controls were found below $-30 \mathrm{~cm}$ (dashed line in Fig. 4b).

When comparing normalized slopes below breakpoints among manipulative treatments, we found that girdle treatment slopes were significantly less than group treatment slopes for all years ( $p<0.05$ ), and were significantly less than clearcut normalized slopes in 2014 $(\mathrm{p}=0.04)$. Clearcut normalized slopes were significantly less than group treatments for 2012, 2013, and 2015 ( $p<0.05$ ). We did not find any significant differences among treatments for normalized intercepts in any year. 


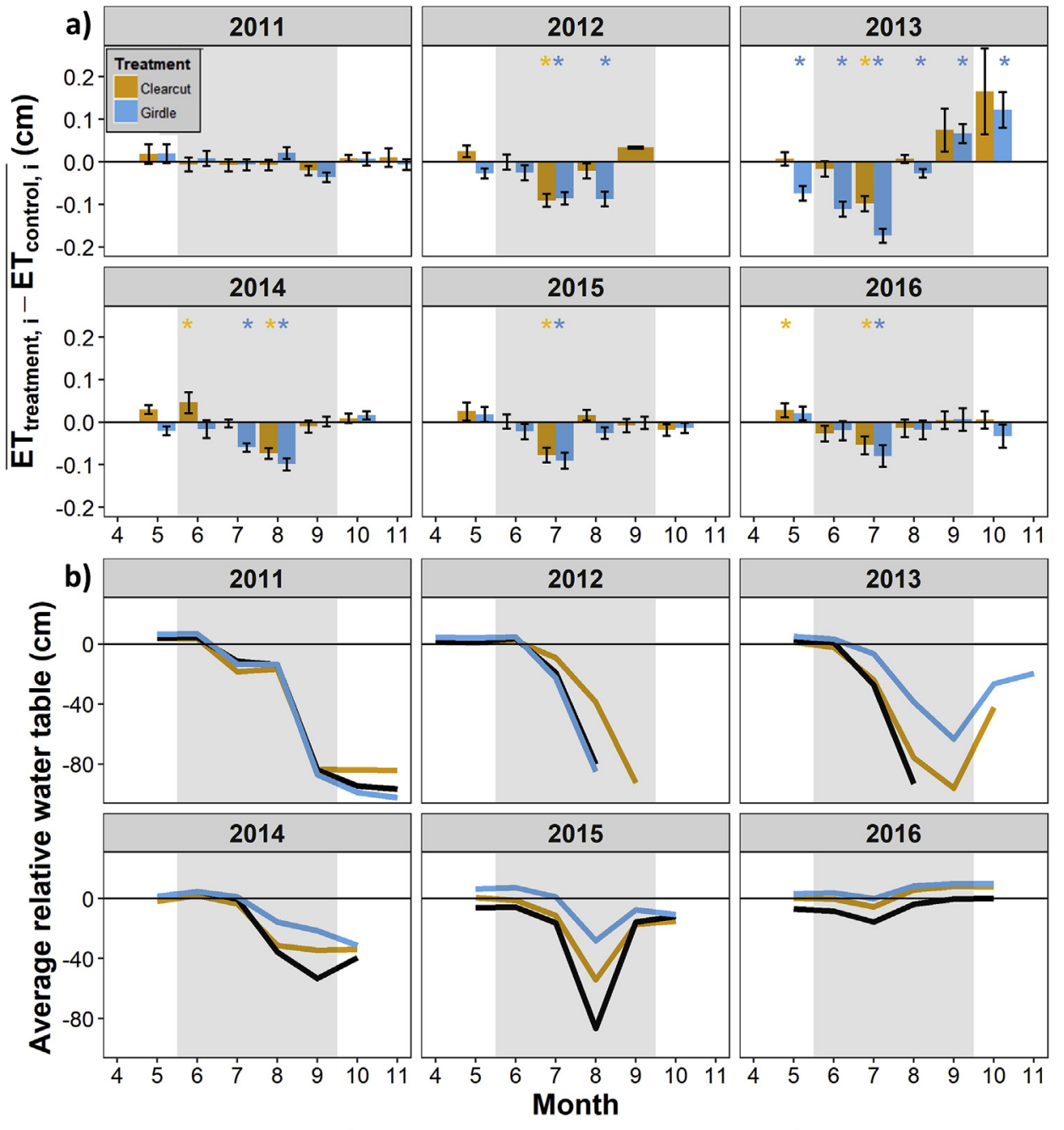

Fig. 5. a) Sum of mean daily differences by month between controls and manipulative treatments, averaged across blocks. Bars are standard errors. Asterisks indicate significant differences $(\mathrm{p}<0.05)$ for monthly average ET rates between controls and girdle and clearcut treatments. Pre-treatment year (2011) generally shows no significant differences among treatments. For post-treatment years (2012-2016), ET in controls is much greater than treatments during mid-summer, but these differences are muted or even reversed in late spring and late fall, especially for clearcuts. Shading indicates leaf on season. b) Average monthly water tables for block 1 (a representative block). Monthly values are missing when water tables were below recording depth. When water tables are similar among control and treatments, differences in daily ET are smallest. Note that not all blocks had water tables below recording depth during fall dormant season months.

Treatment - Clearcut - Control - Girdle

\subsection{Treatment effects on evapotranspiration rates}

Differences in post-treatment water table relationships were coincident with differences in post-treatment ET between controls and clearcut and girdle treatments. We observed no significant differences in post-treatment ET for the group treatment, which aligns with water table observations; as such, the following results focus on clearcut and girdle treatments. In the pretreatment year (2011), there were generally no significant differences (i.e., standard error bars cross zero) in monthly averages of daily ET among treatments, but clear differences emerged for post-treatment years (2012-2016) for both girdle and clearcut treatments (Fig. 5a). During the growing season for black ash (shaded area in Fig. 5a), ET for clearcut and girdle treatments was consistently and often significantly $(\mathrm{p}<0.05$ ) less than control ET for post-treatment years. Average daily ET differences were greatest in June and July, with differences becoming less pronounced throughout the rest of the growing season. Frequently observed growing season differences on the order of -0.05 to $-0.1 \mathrm{~cm} \mathrm{~d}^{-1}$ amount to approximately $25 \%$ reductions in ET relative to control values (cf. column 2 in Table 1).

The trend of lower post-treatment ET in girdle and clearcut treatments relative to controls was often reversed in the dormant season, when black ash trees have no leaves. This dormant season increase in relative ET was most evident in 2013 and 2014, but also is present to a lesser extent in other post-treatment years. We note, however, that observations for fall dormant seasons are more limited due to low water tables, when dry well conditions in control plots often precluded ET comparison. Clearcut treatments typically exhibited the strongest adherence to this dormant season increase in ET relative to controls. These increases in clearcut ET relative to controls were approximately $0.025 \mathrm{~cm} \mathrm{~d}^{-1}$, but could be as great as $0.1 \mathrm{~cm} \mathrm{~d}^{-1}$ (see 2013 in Fig. $5 a$ ). Removing the large increases observed in 2013, these differences represent increases by approximately $10 \%$ in ET relative to controls (cf. column 2 in Table 1).

Interannual differences in precipitation and associated water tables partly explain interannual variability in post-treatment ET differences between controls and girdle and clearcut treatments (Fig. 5b). The highest growing season monthly ET differences tended to occur during dry conditions with deep average water tables across all treatments (2012-2013 vs. 2016; Fig. 5a and b). The effect of water table on differences in dormant season is less clear in part from limited observations. However, examining 2013 suggests that the greatest dormantseason ET increases occur during periods with higher dormant season water tables in girdle and clearcut treatments relative to controls. Greater growing season ET-induced water table decline in control plots led to large dormant season water table differences among treatments, subsequently magnifying differences in dormant season water availability and thus ET. Compare this to 2016, when water tables remained high and were similar among treatments throughout the whole season yielding similar water availabilities; this year had the smallest overall differences in ET among treatments. 
Table 2

Summary of linear mixed-effects model.

\begin{tabular}{|c|c|c|c|c|c|}
\hline Parameter & Estimate & SE & Df & t-value & p-value \\
\hline Intercept & $\begin{array}{l}0.178 \\
(0.234)\end{array}$ & $\begin{array}{l}0.0183 \\
(0.0127)\end{array}$ & 702 & $\begin{array}{l}9.8 \\
(18.4)\end{array}$ & $\begin{array}{l}<0.0001 \\
(<0.0001)\end{array}$ \\
\hline $\begin{array}{l}\text { Average daily PET } \\
\quad(\mathrm{cm})\end{array}$ & $\begin{array}{l}0.273 \\
(0.0133)\end{array}$ & $\begin{array}{l}0.0557 \\
(0.00272)\end{array}$ & 702 & 4.9 & $<0.0001$ \\
\hline Leaf off/on & 0.0433 & 0.00505 & 702 & 8.6 & $<0.0001$ \\
\hline Clearcut & -0.0256 & 0.0162 & 14 & -1.6 & 0.137 \\
\hline Girdle & -0.0271 & 0.0162 & 14 & -1.7 & 0.116 \\
\hline Group & 0.0231 & 0.0173 & 14 & 1.3 & 0.205 \\
\hline Control x WT & $\begin{array}{l}0.000435 \\
(0.0134)\end{array}$ & $\begin{array}{l}0.000139 \\
(0.00427)\end{array}$ & 702 & 3.1 & 0.0018 \\
\hline Clearcut x WT & $\begin{array}{l}0.000695 \\
(0.0259)\end{array}$ & $\begin{array}{l}0.000275 \\
(0.00786)\end{array}$ & 702 & 3.3 & 0.0010 \\
\hline Girdle x WT & $\begin{array}{l}0.000448 \\
(0.0155)\end{array}$ & $\begin{array}{l}0.000239 \\
(0.00702)\end{array}$ & 702 & 2.2 & 0.0273 \\
\hline Group x WT & $\begin{array}{l}0.000144 \\
(0.00396)\end{array}$ & $\begin{array}{l}0.000240 \\
(0.00685)\end{array}$ & 702 & 0.58 & 0.564 \\
\hline
\end{tabular}

Values in parentheses refer to scaled and centered predictor variables. Note: Control group is reference group.

Considering relative ET differences in both growing and dormant seasons, average cumulative differences for all post-treatment years were $-0.16 \mathrm{~cm} \mathrm{yr}^{-1}\left(-1.2 \mathrm{~cm} \mathrm{yr}^{-1}\right.$ without 2013) for clearcut and $-5.1 \mathrm{~cm} \mathrm{yr}^{-1}$ for girdle. These amount to overall reductions in posttreatment ET of $0.3 \%$ (2.4\% without 2013) for clearcuts and $10 \%$ for girdle relative to controls. These numbers align with observed end-ofseason differences in water tables after considering $S_{\mathrm{y}}$ and uncertainties involving unmeasured interception losses, adding confidence to the approach. That is, mean annual ET differences for clearcut $(-1.2 \mathrm{~cm})$ and girdle $(-5.1 \mathrm{~cm})$ yield expected mean differences in predicted and post-treatment water tables $(24 \mathrm{~cm}$ and $102 \mathrm{~cm}$, respectively).

Our linear mixed-effect model indicates significant effects of most candidate predictor variables (Table 2). The signs of the fixed effect parameter estimates align with expectations, lending credence to the structure of the model. PET and water table height exhibited positive influence on ET, and when rescaled in the model, it became clear that they had a similar magnitude of effect on ET (0.0133 versus 0.0134 , Table 2). Comporting with ET observations, girdle and clearcut treatments (but not group) had negative influences on ET, although not significantly. However, treatment interaction with water table was positive for all treatments and was significant except for the group selection treatment. This implies that water table effects on ET differ from controls for clearcut and girdle, but not for group selection. Conditional (full model) and marginal (fixed effects only) coefficients of determination for the model were 0.32 and 0.23 , respectively.

\section{Discussion}

In this work, we studied the ecohydrologic response of black ash wetlands to three alternative management strategies. Our work is motivated by concern over the impending EAB infestation in North American black ash wetlands, where evidence suggests potential for catastrophic shifts to wetter, non-forested wetland states. Our findings support this general prediction, provide insights into the ecohydrologic feedbacks of these systems, and highlight important differences among possible management strategies for mitigating consequences of $\mathrm{EAB}$ infestation.

\subsection{Shifts in hydrologic regime}

H1: Our results support our hypothesis (H1) that hydrologic regimes and their recovery vary depending on management strategy and its influence on vegetation structure. Group-selection treatment $(20 \%$ harvest) exhibited no hydrologic response to treatment, aligning with expectations from upland systems where harvests of less than $20 \%$ produce no observable water yield effects (Bosch and Hewlett, 1982). However, the clear and persistent "wetting up" behavior following clearcut and girdle treatments adds black ash wetlands to the numerous systems that exhibit this behavior with similar levels of disturbance, both in uplands (Bosch and Hewlett, 1982; Arthur et al., 1998; Bearup et al., 2014) and wetlands (Dubé et al., 1995; Sun et al., 2001; Bliss and Comerford, 2002; Pothier et al., 2003). Similar post-clearcut water table rises observed in Michigan black ash wetland depressions (van Grinsven et al., 2017) imply that this response to disturbance is not unique to our study area, and may be common across any landscape or geomorphic position that is dominated by black ash.

Although immediate responses to disturbance may be expected, there is considerable variability among ecosystem hydrologic recovery times in the literature (Brown et al., 2005; Bosch and Hewlett, 1982; Troendle and King, 1985; Jones and Post, 2004; Moore and Wondzell, 2005; Aust et al., 1997; Bliss and Comerford, 2002; Sun et al., 2000). Importantly, we did not observe strong hydrologic recovery in our clearcut and girdled plots, even five years after treatment, although results suggest a more rapid recovery trajectory for clearcut relative to girdle treatments (Fig. 4). Such sustained water table rise has both local (i.e., controls on vegetation composition and growth) and landscapescale consequences. For example, we estimate that end of growing season differences in water table (up to $50 \mathrm{~cm}$ in girdle treatments) due to black ash loss may increase annual water availability by up to $1 \mathrm{~cm}$ per hectare of loss. In Minnesota alone, which contains over 400,000 ha of black ash forest (MN DNR, 2003), this increase in water yield has the potential to substantially alter downstream hydrology by increasing headwater flows to the Mississippi River.

Post-disturbance shifts in hydrologic regime highlight unique black ash imprints on local ecohydrologic interactions. Hydrologic regime shifts were particularly evident from the coherent breakpoint patterning in annual post-treatment water table relationships. For both clearcut and girdle treatments, the consistent breakpoint patterning distinguishes early season, above-ground water levels that decline faster than pre-treatment from belowground water levels that decline slower (Fig. 4b). Despite variable vegetation structure and composition between clearcut and girdle treatments (Looney et al., 2017), both treatments also exhibited similar breakpoint locations centered on ground surface and similar piecewise structure, suggesting common above- and below-ground hydrologic response to black ash mortality. Moreover, both clearcut and girdle treatments exhibited similar departures from pretreatment relationships (i.e., departures for both treatments begin around $\sim-30 \mathrm{~cm}$, Fig. $4 \mathrm{~b}$ ), highlighting the likely effect of black ash loss and its unique water uptake strategy (e.g., via relatively deeper roots) compared to herbaceous replacement vegetation (Looney et al., 2017). In combination, this interannual persistence of altered drawdown patterns (i.e., with a consistent break-point structure and $30 \mathrm{~cm}$ water table departure) indicates that black ash uniquely influences water table position, and imposes a hydrologic regime not observed under other vegetative configurations, underscoring its role as a foundation species in these ecosystems (Youngquist et al., 2017).

H2: Our time series links observed hydrologic response (water table regimes) to the associated ET driver that varies with vegetation structure, and support our prediction (H2) that black ash communities imprint a unique ET signal relative to post-disturbance vegetation communities. Specifically, controls exhibited up to $30 \%$ greater ET during the growing season but up to $50 \%$ less ET during the dormant season than clearcut and girdle treatments (Fig. 5a). The presence of black ash clearly imparts different seasonal ET patterns and resulting water table patterns relative to herbaceous replacement vegetation, likely attributable to differences among phenology, filtering of PET, and rooting depth strategies. Despite these seasonal variations, controls maintained higher cumulative ET relative to treatments even after 5 years. These results support an analogous sap-flux study conducted in harvested black ash systems in Michigan, where findings suggested reductions in 
stand level transpiration in clearcut and girdle treatments during the growing season (van Grinsven et al., 2017). However, we note here that in addition to evaluating transpirative loss from black ash mortality, our study considers changes to ecosystem-scale ET that depend on increased understory contribution with decreasing canopy leaf area (Phillips and Oren, 2001). Black ash trees clearly have a significant influence on the magnitude and temporal structure of evapotranspirative fluxes.

\subsection{Ecohydrologic controls}

Differences in ET and thus water table regimes among plots clearly reveal the importance of vegetation-specific ecohydrologic interactions that influence water availability (e.g., rooting depth) and energy partitioning (via canopy leaf area) (Fig. 1a). Surprisingly, water-limitation due to shallow rooting may be an important control on ET in these wetland systems; our statistical model indicates that water table is equally as important as PET in predicting ET of black ash wetlands (controls) and possibly twice as important in clearcut treatments (Table 2, compare scaled and centered estimates). These results align with a black ash sap flux study that found significant soil moisture control on black ash transpiration, where highest sap fluxes occurred under saturated conditions and much lower sap flux when relative soil water saturation was still as high as $60 \%$ (Telander et al., 2015). Vegetation structure can further influence ET through effects to energy partitioning. For instance, canopy structure filters energy inputs for understory transpiration and direct evaporation of standing and/or soil water (Allen et al., 2017). Additionally, canopy structure likely influences snowfall interception and sublimation and wind redistribution that can result in less snow pack under ash relative to clearcut treatments (Molotch et al., 2007; LaMalfa and Ryle, 2008; Veatch et al., 2009). Changes in both rooting depths and canopy cover following disturbance likely play a large role in observed treatment effects.

Together, vegetation differences in both water access and energy partitioning help explain ET and water table differences among plots and over time. Clearcut treatments (and to a lesser extent, girdle treatments) commonly exhibited higher spring dormant season water tables than predicted pre-treatment relationships (Fig. 4), possibly as a result of greater snowpack. However, clearcuts also often exhibited greater spring dormant season ET than controls and subsequently more rapid spring dormant season drawdown (Fig. 4b) likely due to more open water evaporation from a combination of reduced shading and greater boundary turbulence. We found clear support for the former control on ET, where clearcut (and to a lesser extent girdle) treatments experienced greater daily maximum temperatures compared to control treatments by up to $5{ }^{\circ} \mathrm{C}$ (Fig. S1). However, even though clearcut and girdle treatments received greater sub-canopy energy inputs throughout both dormant and growing seasons, they evapotranspired less than controls in the growing season and on an annual basis, likely due to limited growing season water access via shallow rooting (Fig. 4b). The greater reduction in growing season (and annual) ET and resulting shallower water tables for girdle treatments compared to clearcuts may be because girdle treatments experience the "worst of both worlds". That is, ash mortality results in both reduced overstory transpiration but also maintained shade to limit herbaceous transpiration and open water/soil evaporation (Slesak et al., 2014).

\subsection{Consequent shifts in ecosystem state}

The observed persistent shifts in hydrologic regime coupled with documented shifts in vegetation community from woody to herbaceous (e.g., Looney et al., 2017) indicate a clear change in ecosystem state for the highest levels of disturbance at these sites. Wetland plant communities can act as ecosystem engineers (sensu Jones et al., 1994) by regulating water table dynamics (via controls on ET) and creating conditions that enhance their own success (Ridolfi et al., 2006).
However, the feedbacks that communities develop may be sensitive to abrupt shifts in ecosystem conditions, at which point new positive feedbacks arise, promoting an alternative stable state (Roy et al., 2000, van de Koppel et al., 2004, Kéfi et al., 2016 and references therein). Disturbances that alter vegetation dynamics can cascade to hydrologic regime and, in turn, feedback to influence resultant vegetation composition (Fig. 1a). In wetlands, where water table depth is a dominant control on oxygen and nutrient availability, even moderate rises in the water table following vegetation mortality (e.g., Dubé et al., 1995; Pothier et al., 2003) can alter recruiting vegetation communities (Rodríguez-Iturbe et al., 2007). As such, alternative stable states may be possible where less water tolerant species thrive on deep (er) water tables versus more water tolerant species thriving on shallow (er) water tables (Chambers and Linnerooth, 2001; Ridolfi et al., 2007). We suggest that we have observed such a change in feedbacks in this experiment where complete loss of black ash induced shifts in vegetation communities and their influence on hydrologic regimes, which will in turn likely continue to influence replacement vegetation composition and growth.

Whether this more herbaceous and wetter system will maintain itself through new feedbacks (i.e., become a new stable ecosystem configuration) or whether it will shift back to a forested wetland is uncertain. The stability of the post-disturbance system depends on the strength of the feedbacks that develop between replacement vegetation and hydrology. Explosive herbaceous layer growth following treatment application (Looney et al., 2017) in both the clearcut and girdle treatments may impose a negative feedback (via shade and competition) on establishment of tree seedlings (Terwilliger and Ewel, 1986). However, we submit an additional negative feedback loop on black ash regeneration, where wetter conditions driven by reduced ET from replacement vegetation no longer favors forest plant communities. Evidence for this negative feedback is found throughout Minnesota, where increased wetness in black ash wetlands due to ponding and impoundment from roads correlates strongly with black ash crown dieback (Palik et al. 2011, 2012). Such overstory and seedling sensitivity to disturbed (wetter) hydrologic regime may be a common feature of forested wetlands, where replacement marsh communities are sustained until specific conditions (e.g., drought) support tree seedling regeneration (Aust et al., 1997; Casey and Ewel, 2006). Further, even if EAB-infested black ash wetlands experience ideal recovery conditions for ash seedling regeneration, it is uncertain whether new seedlings will survive due to perpetual mortality from EAB. These negative feedbacks suggest an alternative wetter, and more herbaceous stable state, where return to forested conditions will require intensive management (i.e., planting of replacement tree species that can tolerate the hydrologic conditions, Looney et al., 2015). However, our study was limited to 5 years, and we cannot discount the plausibility of longer-term community succession and regrowth effects (particularly hardwood sprouting) to increase ET and result in more suitable hydrology for forests.

\subsection{Management implications}

Our work has direct implications for future management aimed at mitigating EAB impacts. $\mathrm{EAB}$ infestation, in the absence of mitigation strategies, is likely to result in large-scale loss of forested wetland area and shifts to wetter regimes. The group-selection method applied with small patches (ca. $0.05-0.1$ ha covering $20 \%$ of stand area) maintained pre-disturbance hydrologic regime and could be used to slowly transition black ash stands to communities with other facultative wetland tree species. However, to be successful, this approach has to be implemented well before EAB infestation to allow for multiple harvests (i.e., to reduce black ash extent) with time between each for development of replanted patches. The effectiveness of this approach in operational settings is still unclear, but regional land management organizations are currently interested in utilizing these findings to address the looming EAB threat. 


\section{Conclusions}

Our findings demonstrate clear influence of vegetation structure on ET and associated water table dynamics, highlighting potential consequences of $\mathrm{EAB}$ infestation and different management options. With a do-nothing approach, represented by our girdling treatment, EAB-induced tree mortality will likely generate the greatest hydrologic impact due to both reduced canopy transpiration and maintained shading by dead tree boles that limits subcanopy ET compensation. In this situation, elevated water tables and a herbaceous community may take over and persist for many years. The preemptive clearcut option will also likely result in a shift to wetter conditions, but water tables may recover faster than the do-nothing option. The least hydrologically impactful option that we studied was the group selection option (20\% removal of black ash overstory), highlighting a potential mitigation strategy. Although the scale of potential disturbance is daunting, our findings and other related work are helping to inform such pre-emptive management actions to reduce EAB impacts on black ash wetlands.

\section{Acknowledgments}

This project was funded by the Minnesota Environmental and Natural Resources Trust Fund, the USDA Forest Service Northern Research Station, and the Minnesota Forest Resources Council. Additional funding was provided by the Virginia Tech Forest Resources and Environmental Conservation department, the Virginia Tech Institute for Critical Technology and Applied Science, and the Virginia Tech William J. Dann Fellowship. We gratefully acknowledge the field work and data collection assistance provided by Mitch Slater.

\section{Appendix A. Supplementary data}

Supplementary data related to this article can be found at http://dx. doi.org/10.1016/j.jenvman.2018.05.082.

\section{References}

Allen, S.T., Reba, M.L., Edwards, B.L., Keim, R.F., 2017. Evaporation and the sub-canopy energy environment in a flooded forest. Hydrol. Process. http://dx.doi.org/10.1002/ hyp.11227.

Anderson, M.K., Nelson, G., 2003. Black Ash, Fraxinus Nigra Marsh. NRCS Plant Guide. Natural Resource Conservation Service. http://plants.usda.gov/plantguide/pdf/ csfrni.pdf.

Armstrong, W., Drew, M.C., 2002. Root growth and metabolism under oxygen deficiency. Plant roots: the hidden half 3, 729-761.

Arthur, M.A., Coltharp, G.B., Brown, D.L., 1998. Effects of best management practices on forest streamwater quality in eastern Kentucky. JAWRA J. A. Water Resour. Assoc. 34 (3), 481-495.

Aust, W.M., Schoenholtz, S.H., Zaebst, T.W., Szabo, B.A., 1997. Recovery status of a tupelo-cypress wetland seven years after disturbance: silvicultural implications. For Ecol. Manag. 90 (2-3), 161-169.

Bearup, L.A., Maxwell, R.M., Clow, D.W., McCray, J.E., 2014. Hydrological effects of forest transpiration loss in bark beetle-impacted watersheds. Nat. Clim. Change 4 (6), 481-486.

Bliss, C.M., Comerford, N.B., 2002. Forest harvesting influence on water table dynamics in a Florida flatwoods landscape. Soil Sci. Soc. Am. J. 66 (4), 1344-1349.

Bosch, J.M., Hewlett, J.D., 1982. A review of catchment experiments to determine the effect of vegetation changes on water yield and evapotranspiration. J. Hydrol. 55 (1-4), 3-23.

Brown, A.E., Zhang, L., McMahon, T.A., Western, A.W., Vertessy, R.A., 2005. A review of paired catchment studies for determining changes in water yield resulting from alterations in vegetation. J. hydrol. 310 (1), 28-61.

Casey, W.P., Ewel, K.C., 2006. Patterns of succession in forested depressional wetlands in north Florida, USA. Wetlands 26 (1), 147-160.

Chambers, J.C., Linnerooth, A.R., 2001. Restoring riparian meadows currently dominated by Artemisia using alternative state concepts-the establishment component. Appl. Veg. Sci. 4 (2), 157-166.

Davis, J.C., Shannon, J.P., Bolton, N.W., Kolka, R.K., Pypker, T.G., 2016. Vegetation responses to simulated emerald ash borer infestation in Fraxinus nigra dominated wetlands of Upper Michigan, USA. Can. J. For. Res. 47 (3), 319-330.

Dubé, S., Plamondon, A.P., Rothwell, R.L., 1995. Watering up after clear-cutting on forested wetlands of the St. Lawrence lowland. Water Resour. Res. 31 (7), $1741-1750$

Duke, H.R., 1972. Capillary properties of soils-influence upon specific yield. Transactions of the ASAE 15 (4), 688-0691.
Ellison, A.M., Bank, M.S., Clinton, B.D., Colburn, E.A., Elliott, K., Ford, C.R., Mohan, J., 2005. Loss of foundation species: consequences for the structure and dynamics of forested ecosystems. Front. Ecol. Environ. 3 (9), 479-486.

Erdmann, G.G., Crow, T.R., Ralph Jr., M., Wilson, C.D., 1987. Managing Black Ash in the Lake States.

Heffernan, J.B., 2008. Wetlands as an alternative stable state in desert streams. Ecology 89 (5), 1261-1271.

Jackson, M.B., Colmer, T.D., 2005. Response and adaptation by plants to flooding stress. Ann. Bot. 96 (4), 501-505.

Jones, J.A., Post, D.A., 2004. Seasonal and successional streamflow response to forest cutting and regrowth in the northwest and eastern United States. Water Resour. Res. 40 (5).

Jones, C.G., Lawton, J.H., Shachak, M., 1994. Organisms as ecosystem engineers. In: Ecosystem Management. Springer, New York, NY, pp. 130-147.

Kéfi, S., Holmgren, M., Scheffer, M., 2016. When can positive interactions cause alternative stable states in ecosystems? Funct. Ecol. 30 (1), 88-97.

Klooster, W.S., Herms, D.A., Knight, K.S., Herms, C.P., McCullough, D.G., Smith, A., Cardina, J., 2014. Ash (Fraxinus spp.) mortality, regeneration, and seed bank dynamics in mixed hardwood forests following invasion by emerald ash borer (Agrilus planipennis). Biol. Invasions 16 (4), 859-873.

Kozlowski, T.T., 2002. Physiological-ecological impacts of flooding on riparian forest ecosystems. Wetlands 22 (3), 550-561.

Kreuzwieser, J., Rennenberg, H., 2014. Molecular and physiological responses of trees to waterlogging stress. Plant Cell Environ. 37 (10), 2245-2259.

Knight, K.S., Brown, J.P., Long, R.P., 2013. Factors affecting the survival of ash (Fraxinus spp.) trees infested by emerald ash borer (Agrilus planipennis). Biol. Invasions 15 (2), 371-383.

LaMalfa, E.M., Ryle, R., 2008. Differential snowpack accumulation and water dynamics in aspen and conifer communities: implications for water yield and ecosystem function. Ecosystems 11 (4), 569-581.

Lindgren, R., 1996. Hydrology and Ground-water Quality of Glacial-drift Aquifers, Leech Lake Indian Reservation, north-central Minnesota. U.S. Geological Survey WaterResources Investigations report 95-4077.

Loheide, S.P., Butler, J.J., Gorelick, S.M., 2005. Estimation of groundwater consumption by phreatophytes using diurnal water table fluctuations: a saturated-unsaturated flow assessment. Water Resour. Res. 41 (7)

Looney, C.E., D'Amato, A.W., Palik, B.J., Slesak, R.A., 2015. Overstory treatment and planting season affect survival of replacement tree species in emerald ash borer threatened Fraxinus nigra forests in Minnesota, USA. Can. J. For. Res. 45, 1728-1738.

Looney, C.E., D'Amato, A.W., Fraver, S., Palik, B.J., Reinikainen, M.R., 2016. Examining the influences of tree-to-tree competition and climate on size-growth relationships in hydric, multi-aged Fraxinus nigra stands. For. Ecol. Manag. 375, 238-248.

Looney, C.E., D'Amato, A.W., Palik, B.J., Slesak, R.A., Slater, M.A., 2017. The response of Fraxinus nigra forest ground-layer vegetation to emulated emerald ash borer mortality and management strategies in northern Minnesota, USA. For. Ecol. Manag. 389, 352-363.

Marani, M., Silvestri, S., Belluco, E., Ursino, N., Comerlati, A., Tosatto, O., Putti, M., 2006. Spatial organization and ecohydrological interactions in oxygen-limited vegetation ecosystems. Water Resour. Res. 42 (6).

McLaughlin, D.L., Cohen, M.J., 2014. Ecosystem specific yield for estimating evapotranspiration and groundwater exchange from diel surface water variation. Hydrol. Process. 28 (3), 1495-1506.

Minnesota Department of Natural Resources (MN DNR), 2003. Field Guide to the Native Plant Communities of Minnesota: the Laurentian Mixed Forest Province. Ecological Land Classification Program, Minnesota County Biological Survey, and Natural Heritage and Nongame Research Program. MNDNR, St. Paul, MN.

Molotch, N.P., Blanken, P.D., Williams, M.W., Turnipseed, A.A., Monson, R.K., Margulis, S.A., 2007. Estimating sublimation of intercepted and sub-canopy snow using eddy covariance systems. Hydrol. Process. 21 (12), 1567-1575.

Moore, R., Wondzell, S.M., 2005. Physical hydrology and the effects of forest harvesting in the Pacific Northwest: a review. JAWRA J. Am. Water Resou. Asso. 41 (4), 763-784 Nachabe, M. H. (2002). Analytical expressions for transient specific yield and shallow water table drainage. Water Resources Research, 38(10).

Muggeo, Vito M.R., 2003. Estimating regression models with unknown break-points. Stat. Med. 22, 3055-3071.

Muggeo, Vito M.R., 2008. Segmented: an R package to fit regression models with brokenline relationships. R News 8 (1), 20-25. https://cran.r-project.org/doc/Rnews/.

Palik, B.J., Ostry, M.E., Venette, R.C., Abdela, E., 2011. Fraxinus nigra (black ash) dieback in Minnesota: regional variation and potential contributing factors. For. Ecol. Manag. 261 (1), 128-135.

Palik, B.J., Ostry, M.E., Venette, R.C., Abdela, E., 2012. Tree regeneration in black ash (Fraxinus nigra) stands exhibiting crown dieback in Minnesota. For. Ecol. Manag. 269, 26-30.

Phillips, N., Oren, R., 2001. Intra- and inter-annual variation in transpiration of a pine forest. Ecol. Appl. 11, 385-396.

Ponnamperuma, F.N., 1984. Effects of Flooding on Soils. Flooding and Plant Growth. pp. 9-45.

Pothier, D., Prévost, M., Auger, I., 2003. Using the shelterwood method to mitigate water table rise after forest harvesting. For. Ecol. Manag. 179 (1), 573-583.

R Core Team, 2016. R: a Language and Environment for Statistical Computing. R Foundation for Statistical Computing, Vienna, Austria URL: https://www.R-project. org/.

Ridolfi, L., D'Odorico, P., Laio, F., 2006. Effect of vegetation-water table feedbacks on the stability and resilience of plant ecosystems. Water Resour. Res. 42 (1).

Ridolfi, L., D'Odorico, P., Laio, F., 2007. Vegetation dynamics induced by phreatophyte-aquifer interactions. J. Theor. Biol. 248 (2), 301-310. 
Rodríguez-Iturbe, I., D'Odorico, P., Laio, F., Ridolfi, L., Tamea, S., 2007. Challenges in humid land ecohydrology: interactions of water table and unsaturated zone with climate, soil, and vegetation. Water Resour. Res. 43 (9).

Roy, V., Ruel, J.C., Plamondon, A.P., 2000. Establishment, growth and survival of natural regeneration after clearcutting and drainage on forested wetlands. For. Ecol. Manag. 129 (1), 253-267.

Sebestyen, S.D., Dorrance, C., Olson, D.M., Verry, E.S., Kolka, R.K., Elling, A.E., Kyllander, R., 2011. Chapter 2. Long-term monitoring sites and trends at the Marcell Experimental Forest. In: Kolka, R.K., Sebestyen, S.D., Verry, E.S., Brooks, K.N. (Eds.), Peatland Biogeochemistry and Watershed Hydrology at the Marcell Experimental Forest. CRC Press, Boca Raton, FL, pp. 15-71.

Slesak, R.A., Lenhart, C.F., Brooks, K.N., D'Amato, A.W., Palik, B.J., 2014. Water table response to harvesting and simulated emerald ash borer mortality in black ash wetlands in Minnesota, USA. Can. J. For. Res. 44 (8), 961-968.

Smith, A., Herms, D.A., Long, R.P., Gandhi, K.J., 2015. Community composition and structure had no effect on forest susceptibility to invasion by the emerald ash borer (Coleoptera: Buprestidae). Can. Entomol. 147 (3), 318-328.

Soil Survey Staff, 2014. Natural Resources Conservation Service, United States Department of Agriculture. Web Soil Survey. Available online at the following link: https://websoilsurvey.sc.egov.usda.gov/, Accessed date: 1 October 2017.

Sun, G., Riekerk, H., Kornhak, L.V., 2000. Ground-water-table rise after forest harvesting on cypress-pine flatwoods in Florida. Wetlands 20 (1), 101-112.

Sun, G., McNulty, S.G., Shepard, J.P., Amatya, D.M., Riekerk, H., Comerford, N.B., Swift, L., 2001. Effects of timber management on the hydrology of wetland forests in the southern United States. For. Ecol. Manag. 143 (1), 227-236.

Telander, A.C., Slesak, R.A., D'Amato, A.W., Palik, B.J., Brooks, K.N., Lenhart, C.F., 2015. Sap flow of black ash in wetland forests of northern Minnesota, USA: hydrologic implications of tree mortality due to emerald ash borer. Agric. For. Meteorol. 206, 4-11.

Terwilliger, V.J., Carter Ewel, K., 1986. Regeneration and growth after logging Florida pondcypress domes. Forest Sci. 32 (2), 493-506.
Troendle, C.A., King, R.M., 1985. The effect of timber harvest on the Fool Creek watershed, 30 years later. Water Resour. Res. 21 (12), 1915-1922.

United States Department of Agriculture (USDA), 2017. Cooperative Emerald Ash Borer Project: Initial County EAB Detections in North America. http://www. emeraldashborer.info/documents/MultiState_EABpos.pdf, Accessed date: 1 October 2017.

Van de Koppel, J., Wal, D.V.D., Bakker, J.P., Herman, P.M., 2004. Self-organization and vegetation collapse in salt marsh ecosystems. Am. Nat. 165 (1), E1-E12.

van Grinsven, M.J., Shannon, J.P., Davis, J.C., Bolton, N.W., Wagenbrenner, J.W., Kolka, R.K., Grant Pypker, T., 2017. Source water contributions and hydrologic responses to simulated emerald ash borer infestations in depressional black ash wetlands. Ecohydrology 10 (7).

Veatch, W., Brooks, P.D., Gustafson, J.R., Molotch, N.P., 2009. Quantifying the effects of forest canopy cover on net snow accumulation at a continental, mid-latitude site. Ecohydrology 2 (2), 115-128.

Wang, C., Wang, Q., Meire, D., Ma, W., Wu, C., Meng, Z., van de Koppel, J., Troch, P., Verhoeven, R., De Mulder, T., Temmerman, S., 2016. Biogeomorphic feedback between plant growth and flooding causes alternative stable states in an experimental floodplain. Adv. Water Resour. 93, 223-235.

Watras, C.J., Morrison, K.A., Rubsam, J.L., Buffam, I., 2017. Estimates of evapotranspiration from contrasting Wisconsin peatlands based on diel water table oscillations. Ecohydrology 10 (4).

White, W.N., 1932. A Method of Estimating Ground-water Supplies Based on Discharge by Plants and Evaporation from Soil: Results of Investigations in Escalante Valley, Utah, vol. 659 US Government Printing Office.

Wright, J.W., Rauscher, H.M., 1990. Fraxinus nigra Marsh. black ash. Silvics North Am. 2, 344-347.

Youngquist, M.B., Eggert, S.L., D'Amato, A.W., Palik, B.J., Slesak, R.A., 2017. Potential effects of foundation species loss on wetland communities: a case study of black ash wetlands threatened by emerald ash borer. Wetlands 1-13. 